\title{
Structural Basis of Topotecan-DNA Recognition Probed by Flow Linear Dichroism, Circular Dichroism, and Raman Spectroscopy
}

\author{
Sergei Streltsov, ${ }^{\dagger}$ Alyona Sukhanova,,${ }^{\ddagger}$ Andrey Mikheikin, ${ }^{\dagger}$ Sergei Grokhovsky, ${ }^{\dagger} §$ Alexei Zhuze, ${ }^{\dagger}$ \\ Irina Kudelina," Konstantin Mochalov," Vladimir Oleinikov," Jean-Claude Jardillier," and \\ Igor Nabiev* \\ EA3306, Institut Fédératif de Recherche $n^{\circ} 3$ "Biomolécules", UFR de Pharmacie, \\ Université de Reims Champagne-Ardenne, 51100 Reims, France, Laboratory of DNA-Protein Recognition, \\ Engelhardt Institute of Molecular Biology, Russian Academy of Sciences, Moscow 117984, Russia, \\ Center for Medical Studies, University of Oslo, Norway, and Shemyakin-Ovchinnikov Institute of Bioorganic \\ Chemistry, Russian Academy of Sciences, Moscow 117871, Russia
}

Received: March 29, 2001; In Final Form: July 9, 2001

\begin{abstract}
Camptothecin (CPT) and its clinically important antitumor derivative topotecan (Tpt) were traditionally described as unique antitumor compounds exhibiting no affinity toward DNA alone or DNA topoisomerase I (top1) alone but interacting with both the enzyme and the DNA within the so-called ternary cleavable complexes. We present here the first experimental data on the molecular structure and geometry of TptDNA complexes in solution. Tpt interacts with DNA within the DNA minor groove and demonstrates the preferential binding to GC-rich DNA. The flow linear dichroism (FLD) spectra show that the Tpt binds DNA only in lactone form and its chromophore forms the angle nearly $55^{\circ}$ with the DNA long axis. Induced circular dichroism (CD) data independently confirm conclusions about Tpt preferable orientation drawn from the FLD experiments. The Raman spectroscopy data confirm the FLD and CD results and further demonstrate direct interactions of Tpt lactone ring with $\mathrm{dG}$. The capability of Tpt to bind DNA in the minor groove of GC-rich DNA regions must be taken into account when considering molecular structure of ternary cleavable complexes of CPTs, DNA, and top1 in solution.
\end{abstract}

\section{Introduction}

The human DNA topoisomerase I (top1) inhibitors of the camptothecin (CPT) family exhibit their antitumor activity through stabilization of the top1-DNA reaction intermediate known as a cleavable complex. ${ }^{1}$ For many years, the CPT was described as a unique antitumor compound exhibiting no affinity toward the DNA alone ${ }^{2-6}$ or the top 1 alone. ${ }^{6}$ It was proved to be able to interact with both the enzyme and the DNA, forming a ternary complex, thus preventing the DNA strand religation after top1-DNA specific recognition and DNA single-strand cleavage reactions. ${ }^{7}$

In the past decade, the mixed observations of the possible interaction between CPT or derivatives with the DNA have been reported in the literature. ${ }^{8,9}$ According to the theoretical "drugstacking" model, ${ }^{9}$ CPTs may interact with the DNA base at the 5'-terminus of top1-induced DNA breaks, and their planar multiring system may bind by stacking preferentially to $\mathrm{dG}$. Recently, two clinically important CPT derivatives, topotecan (Tpt) and irinotecan, were shown to be capable of interacting directly with double-stranded DNA. ${ }^{10}$ In the further NMR studies, the lactone form of Tpt was shown to be capable of binding noncovalently to both double-stranded and single-

* To whom correspondence should be addressed. E-mail: igor.nabiev@ univ-reims.fr. Phone \& fax: +33-326-91-81-27.

†ngelhardt Institute of Molecular Biology, Russian Academy of Sciences.

$\doteqdot$ UFR de Pharmacie, Université de Reims Champagne-Ardenne.

$\S$ Center for Medical Studies, University of Oslo.

" Shemyakin-Ovchinnikov Institute of Bioorganic Chemistry, Russian Academy of Sciences. stranded DNA structures in the absence of top $1 .{ }^{11}$ The data on the sequence specificity of the Tpt-DNA binding are contradictory. Yao et al. reported sequence specificity of Tpt lactone binding to duplex DNA which was comprised of alternating purine- pyrimidine sequences that contained $\mathrm{dT},{ }^{11}$ whereas Yang et al. claimed specific Tpt binding to $\mathrm{dGdC}$ rather than to dAdT sequences. ${ }^{10}$

Two theoretical models of binding of CPT to the covalent top1-DNA complex have been recently proposed, both attempting to account for the results of numerous CPT structureactivity studies and top 1 mutagenesis data. ${ }^{9,12,13}$ Neither model explains the requirement for a guanine at the +1 position of the DNA scissile strand in the process of DNA cleavage by top1 in the presence of CPT drugs. Both models suggest involvement of the 20-OH group of CPT (Figure 1) in a donor $\mathrm{H}$-bond with an enzyme side chain functional group, whereas some very recently synthesized CPT derivatives bind the top $1-$ DNA binary complex despite the absence of a substituent at C-20 capable of contributing a donor H-bond. ${ }^{14}$ Additionally, the crystal structure of top1 without DNA was not solved although the absence of enzyme structure modifications upon DNA binding was claimed based on analysis of the top1-DNA complex X-ray structure. On the contrary, the Raman spectroscopy comparative studies of top1 and of its complex with the suicide DNA substrate in solution revealed significant top1 conformational transitions after the cleavage step in the reaction of binding and cleavage of DNA. ${ }^{15}$ An additional studies of complexes of CPTs with the DNA and top1 in solution will be required in order to elucidate the molecular basis of the inhibition of top1 by these drugs. 


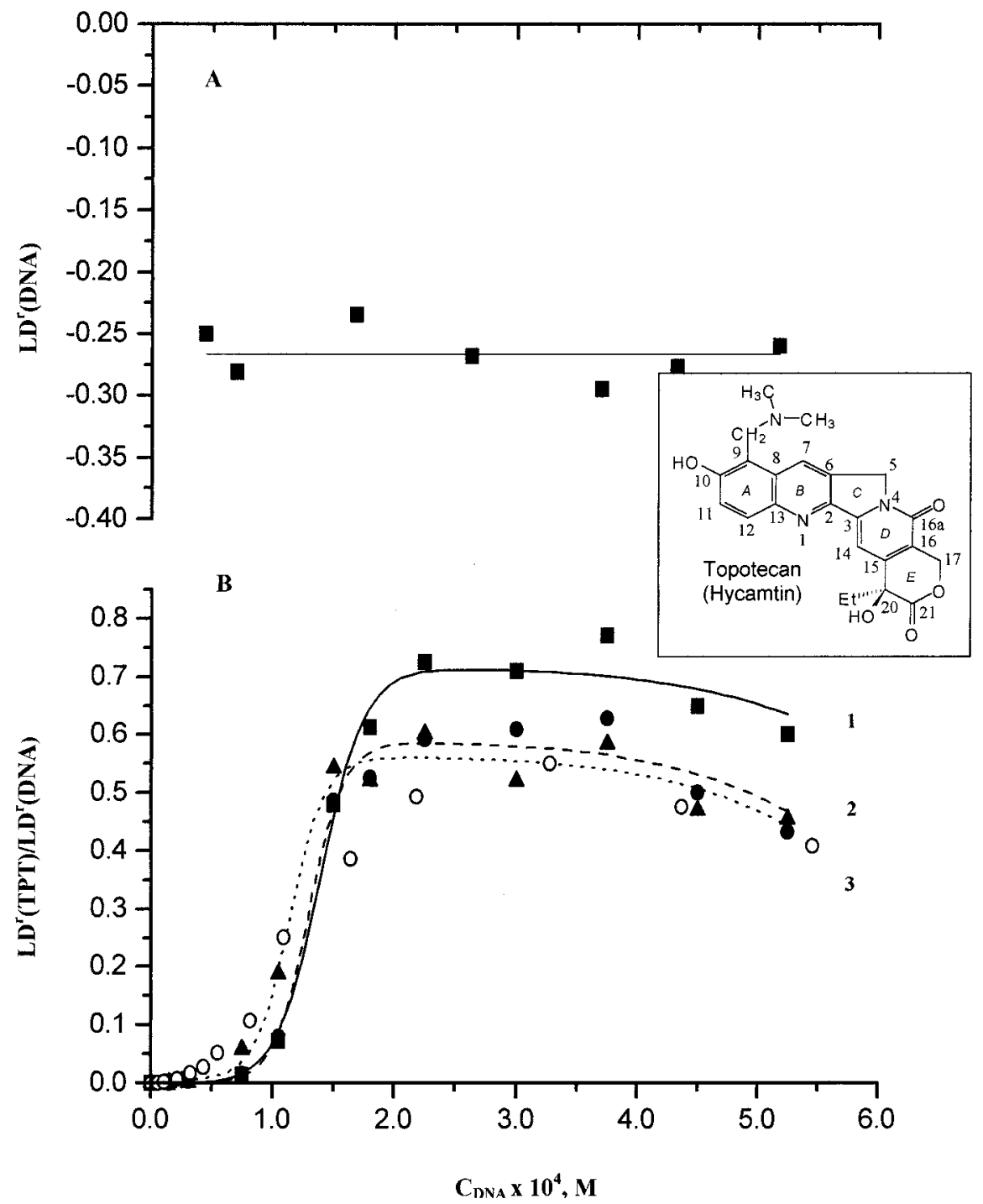

Figure 1. Dependence of the DNA and of the DNA-bound topotecan linear dichroism on the DNA concentration. Panel A: Reduced linear dichroism $\mathrm{LD}^{\mathrm{r}}(\mathrm{DNA})$ at $260 \mathrm{~nm}$ as a function of DNA concentration in the flowing solution $(1 \mathrm{mM}$ cacodylate buffer, $\mathrm{pH}=6.8)$. Panel $\mathrm{B}$ : $\mathrm{LD}^{\mathrm{r}}$ $(\mathrm{Tpt}) / \mathrm{LD}^{\mathrm{r}}$ (DNA) values measured at $390 \mathrm{~nm}$ (the maximum of LD spectrum of DNA-bound topotecan), as a function of DNA concentration. The signals are recorded in $2 \mathrm{~h}$ (solid line, 1), in $24 \mathrm{~h}$ (dashed line, 2), and in $48 \mathrm{~h}$ (dotted line, 3 ) after preparation of the DNA-Tpt complexes. $C_{\mathrm{Tpt}}$ $=1.4 \times 10^{-4} \mathrm{M}(1 \mathrm{mM}$ cacodylate buffer, $\mathrm{pH}=6.8$, cuvette path length $0.1 \mathrm{~cm})$. Insert: chemical structure of topotecan.

We report here the combined flow linear dichroism (FLD), circular dichroism (CD), and Raman spectroscopy study of TptDNA interactions in the absence of top1. Tpt chromophore is found to be oriented at the nearly $55^{\circ}$ angle to the DNA long axis and involved in interaction with the DNA base(s). The competitive DNA binding by Tpt and distamycin A followed with the FLD spectroscopy revealed that the Tpt may bind the DNA within the minor groove. FLD spectroscopy of Tpt binding with calf thymus DNA and bacterophage T4 DNA further confirmed this conclusion, and comparative analysis of its binding with the different DNA polymers demonstrated preferential binding with $\mathrm{dG}$ rather than with $\mathrm{dA}$ or $\mathrm{dT}$. The Raman spectra reveal the nature of interaction of Tpt with DNA and with each of DNA nucleosides and provide direct evidence of $\mathrm{H}$-bonds formation between the Tpt D and E rings and $\mathrm{dG}$ within the Tpt-DNA complexes.

\section{Experimental Section}

Materials. Calf thymus DNA, bacteriophage T4 DNA, the double-stranded poly $(\mathrm{dA}-\mathrm{dT})$ poly $(\mathrm{dA}-\mathrm{dT})$ polymer, and Nacacodylate were purchased from Sigma. Poly(dA)poly(dT), poly $(\mathrm{dG}-\mathrm{dC}) \operatorname{poly}(\mathrm{dG}-\mathrm{dC})$, and poly $(\mathrm{dG}) \operatorname{poly}(\mathrm{dC})$ polymers were purchased from $\mathrm{P}-\mathrm{L}$ Biochemicals. All DNAs were solubilized in the $1 \mathrm{mM}$ cacodylate buffer ( $\mathrm{pH} \mathrm{6.8)} \mathrm{for} 3$ days and further dialyzed 3 times against the same buffer. Each dialysis was performed for $12 \mathrm{~h}$. Concentrations of calf thymus DNA, bacteriophage T4 DNA, poly $(\mathrm{dA}-\mathrm{dT})$ poly $(\mathrm{dA}-\mathrm{dT})$, poly $(\mathrm{dG}-\mathrm{dC})$ poly $(\mathrm{dG}-\mathrm{dC})$, poly $(\mathrm{dA})$ poly $(\mathrm{dT})$, and poly $(\mathrm{dG})-$ poly $(\mathrm{dC})$ were determined by $\mathrm{UV}-$ vis using the molar extinction coefficients $\epsilon_{260}=6600, \epsilon_{262}=6600, \epsilon_{254}=8400, \epsilon_{260}=$ 6000 , and $\epsilon_{253}=7400$, calculated for one base of DNA. ${ }^{16}$

Hycamtin $^{\circledR}$ (topotecan, Tpt, Figure 1, insert) was supplied by SmithKline Beecham and purified by the HPLC. The molar extinction coefficient for Tpt was determined by UV-vis and was found to be $\epsilon_{380}=20000 \mathrm{M}^{-1} \mathrm{~cm}^{-1}$. Distamycin A (Dst) was purchased from Serva and used as received. Molar extinction coefficient $\epsilon_{303}=34000 \mathrm{M}^{-1} \mathrm{~cm}^{-1}$ was used for the distamycin A concentration determination. ${ }^{17}$

Tpt-DNA complexes were prepared from the $2 \times 10^{-4} \mathrm{M}$ Tpt stock solution in $1 \mathrm{mM}$ cacodylate buffer $(\mathrm{pH} \mathrm{6.8)}$ ) and the $1 \mathrm{mM}$ DNA stock solution in the same buffer as that of the probes, with a fixed concentration of Tpt and varied concentra- 
tions of DNA. The complexes were incubated for $72 \mathrm{~h}$. The samples for analysis of competitive Tpt and distamycin A binding with the DNA were prepared by addition of the distamycin A from the $1 \mathrm{mM}$ stock methanol solution to the Tpt-DNA complexes prepared as described above.

Spectroscopy. UV-vis spectra were recorded with a Cary118 UV-vis spectrophotometer, and CD spectra were obtained with a JASCO 500C dichrograph.

Raman spectra were excited with the $647.1 \mathrm{~nm}$ line of a krypton laser (Spectra Physics, model 164-03) using 200 mW of radiant power at the sample. The spectra were collected on a Ramanor HG-2S (Jobin Yvon) spectrometer with an Anaspec $300 \mathrm{~S}$ premonochromator. All spectra were registered upon scanning at $2 \mathrm{~cm}^{-1}$ step, and the integration time of each point was $3 \mathrm{~s}$. Data accumulation of 30-40 independent scans with time averaging was used. The stability of the samples during laser irradiation was controlled by comparison of the spectra as a function of time. The spectra of unbound Tpt, nucleosides, DNA, and complexes of Tpt with DNA and nucleosides were obtained by subtracting the standard buffer spectra recorded at exactly the same conditions from the corresponding Tpt/buffer, nucleosides/buffer, and DNA/buffer spectra. The spectra of Tpt within the complexes with DNA and nucleosides were obtained by subtracting the spectra of DNA or nucleosides from the spectra of corresponding complexes. The spectra were subjected to curve decomposition, when necessary, using the SpectraCalc software. ${ }^{15}$ All spectra were reproduced 3 times for different preparations of the sample.

FLD spectra of DNA and drug-DNA complexes were recorded with JASCO 500C dichrograph equipped with the linear dichroism option to transform circular polarized light to the linear one. The self-made flow cell with optical length 1 $\mathrm{mm}$ and volume $200 \mathrm{~mL}$ was used for orientation of DNA in the flow. ${ }^{18}$ Only the molecules of significant length (polymers) or the ligands bound to such polymers may be oriented in the flow and to induce the FLD signal. ${ }^{19}$ The FLD of the polymers and of the polymer-bound ligands is defined as the difference between absorption of light polarized parallel and perpendicular to the direction of the flow: $\mathrm{LD}=A_{\|}-A$ Another value, known to be more convenient for the studies of ligand-DNA interactions, is the so-called reduced linear dichroism $\left(\mathrm{LD}^{\mathrm{r}}\right)$, defined as $\mathrm{LD}^{\mathrm{r}}=\mathrm{LD} / A$, were $A$ is absorption of the ligand molecules bound to the nonoriented DNA. ${ }^{19}$ For the DNA solution, the value of $\mathrm{LD}^{\mathrm{r}}$ at $260 \mathrm{~nm}$

$$
\mathrm{LD}^{\mathrm{r}}(\mathrm{DNA})={ }_{3}^{3} S\left(3 \cos ^{2} \alpha_{\mathrm{DNA}}-1\right)
$$

were $\alpha$ is the angle between the direction of the DNA base pair electronic transition corresponding to absorption at $260 \mathrm{~nm}$ and the direction of the DNA long axis. ${ }^{20}$ This angle, determined by electric linear dichroism technique for the B-form of the calf thymus DNA, was shown to be $72^{\circ} .^{21}$ Parameter $S$ does not depend on the wavelength of the LD measurement. It shows the degree of DNA orientation in the flow and depends on the speed of the flow, the geometry of the cell, the viscosity of solution, etc. When the ligand-DNA interaction is concerned, parameter $S$ may be excluded when the following expression is used:

$$
\operatorname{LD}^{\mathrm{r}}(\mathrm{b} .1 .) / \mathrm{LD}^{\mathrm{r}}(\mathrm{DNA})=\left(3 \cos ^{2} \alpha_{\mathrm{bl}}-1\right) /\left(3 \cos ^{2} 72^{\circ}-1\right)
$$

where $\mathrm{LD}^{\mathrm{r}}\left(\mathrm{b}\right.$.1.) and $\mathrm{LD}^{\mathrm{r}}(\mathrm{DNA})$ are the $\mathrm{LD}^{\mathrm{r}}$ values in the regions of absorption of bound ligand (b.l.) and of DNA, respectively, and $\alpha_{b l}$ is the angle between the direction of the bound ligand electronic transition and the DNA long axis. ${ }^{22,23}$

In expression 2, the $\mathrm{LD}^{\mathrm{r}}(\mathrm{b} .1.) / \mathrm{LD}^{\mathrm{r}}(\mathrm{DNA})$ ratio does not depend on $S$ but depends on $\alpha_{\mathrm{bl}}$ being characteristic of the geometry of ligand-DNA complex. It is important to note that the $\mathrm{LD}^{\mathrm{r}}(\mathrm{b} .1$. $\mathrm{LD}^{\mathrm{r}}$ (DNA) ratio characterizes the geometry of the ligand-DNA complex only under condition when practically all ligand molecules are bound to the DNA.

If the chromophore of the bound ligand has only one electronic transition, expression 2 presents the angle between direction of this electronic transition and the DNA long axis. If the chromophore of the bound ligand has different nonparallel electronic transitions, the measurements of the $\mathrm{LD}^{\mathrm{r}}(\mathrm{b} .1$. $)$ at the corresponding wavelengths, followed by application of expression [2], enables determining an orientation of the plane of the bound ligand chromophore relative to the DNA long axis. The simplest situation corresponds to the case when the ligand's chromophore is perpendicular to the DNA long axis. In this case, the values of $\alpha_{\mathrm{bl}}$ for all nonparallel ligand's electronic transitions are nearly the same and are close to $90^{\circ}$. In this particular situation, the value of $\operatorname{LD}^{\mathrm{r}}(\mathrm{b}$.l.) does not depend on the wavelength and should be presented by the line parallel to the wavelength axis of the graph.

Calculation of Directions of the Transition Electric Dipoles of Topotecan. Geometrical parameters of Tpt chromophore (Figure 2, insert) were calculated using the semiempirical model AM1. ${ }^{24}$ Parameters of excited state were determined using the INDO/S method. ${ }^{25}$ Minimum 19 occupied, and 19 unoccupied molecular orbitals (723 configurations) were taken into account in the calculations of configuration interaction.

\section{Results}

Dependence of the $\operatorname{LD}^{\mathrm{r}}(\mathrm{DNA})$ and $\mathrm{LD}^{\mathrm{r}}(\mathrm{b.l}.) / \mathrm{LD}^{\mathrm{r}}(\mathrm{DNA})$ on the DNA Concentration. Figure 1A shows the dependence of the $\mathrm{LD}^{\mathrm{r}}(\mathrm{DNA})$ at $260 \mathrm{~nm}$ on the concentration of DNA in the flowing solution. In the DNA concentration range of $0.2-5.5$ $\times 10^{-4} \mathrm{M}$ bp used for the study of the Tpt-DNA binding, the value of $\mathrm{LD}^{\mathrm{r}}(\mathrm{DNA})$ is equal to $(-0.266)$. This value was used in the all further calculations.

To determine the DNA concentration at which all Tpt molecules are bound with the DNA and to calculate the angle between the plane of the Tpt chromophore and the DNA long axis, we have measured $\mathrm{LD}^{\mathrm{r}}(\mathrm{b} .1.) / \mathrm{LD}^{\mathrm{r}}(\mathrm{DNA})$ values as a function of DNA concentration. The measurements of FLD were performed in the absorption maximum of DNA-bound Tpt (see below) at the constant $\left(1.4 \times 10^{-5} \mathrm{M}\right)$ Tpt concentration

Figure 1B shows variations of the $\mathrm{LD}^{\mathrm{r}}(\mathrm{b} .1.) / \mathrm{LD}^{\mathrm{r}}(\mathrm{DNA})$ ratios as a function of DNA concentration. The FLD signals were recorded in 2, 24, and $48 \mathrm{~h}$ after preparation of the DNA/Tpt complexes (curves $1-3$, respectively). The data of Figure 1B show that the kinetic of Tpt-DNA binding is quite slow. All curves have the same form and differ only in the absolute values of the $\mathrm{LD}^{\mathrm{r}}(\mathrm{b} .1.) / \mathrm{LD}^{\mathrm{r}}(\mathrm{DNA})$ ratios.

The time-dependent decrease of the $\mathrm{LD}^{\mathrm{r}}(\mathrm{b} .1.) / \mathrm{LD}^{\mathrm{r}}(\mathrm{DNA})$ ratios is a result of hydrolysis of the Tpt's lactone ring at physiological $\mathrm{pH}$. This kinetic may be followed by the fluorescence as described ${ }^{26}$ and in our experimental conditions ( $1 \mathrm{mM}$ cacodylate buffer, $\mathrm{pH}$ 6.8) was found to be extremely slow: only $14 \%$ of Tpt was hydrolyzed within $2 \mathrm{~h}$, and only $27 \%$ of Tpt was hydrolyzed within $24 \mathrm{~h}$. Moreover, the extent of Tpt hydrolysis, determined from the fluorescence spectra, was found to be correlated exactly with the extent of the decrease of $\mathrm{LD}^{\mathrm{r}}(\mathrm{b} .1.) / \mathrm{LD}^{\mathrm{r}}(\mathrm{DNA})$ ratio in the FLD measurements 

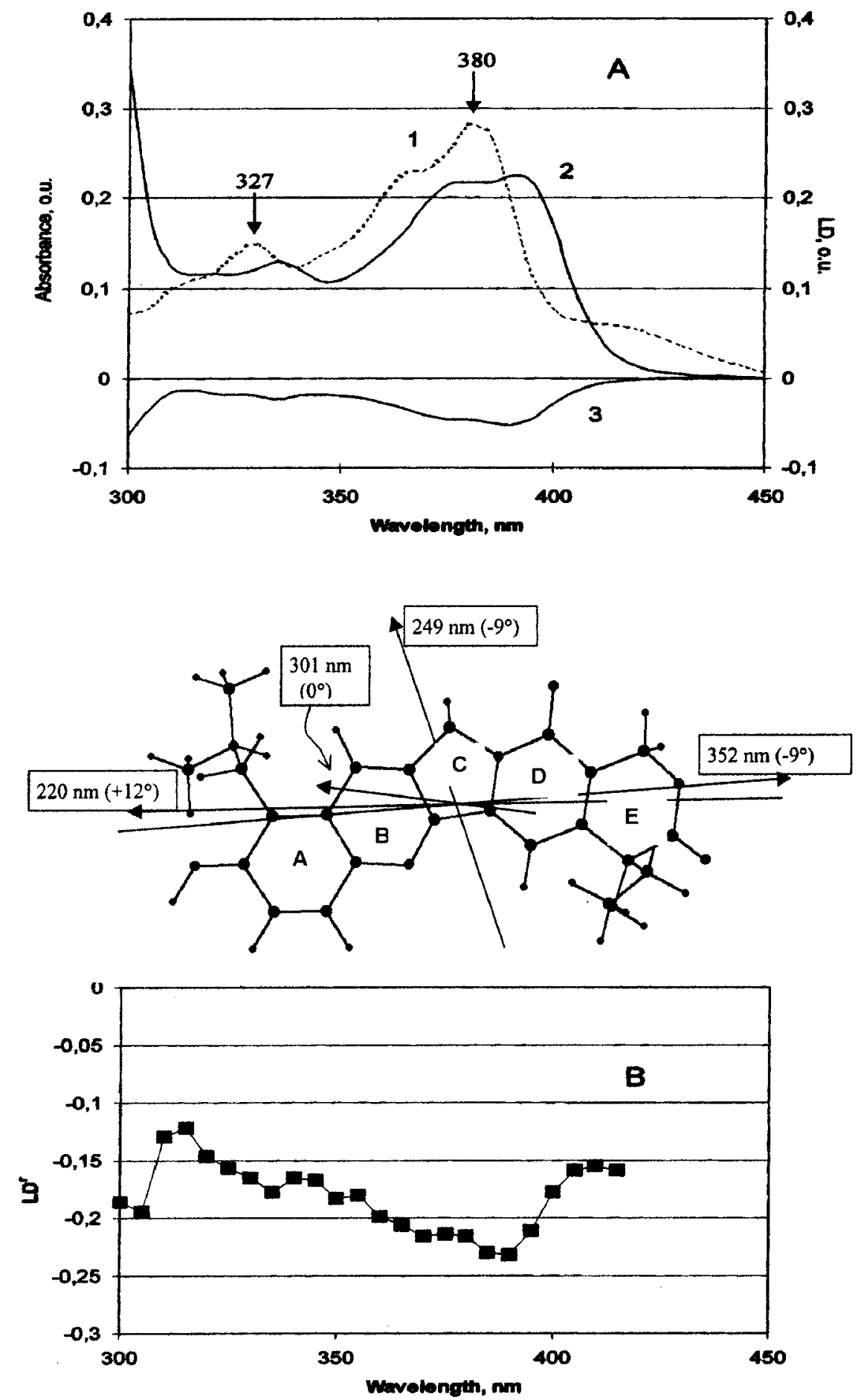

Figure 2. UV-vis and LD spectra of topotecan and of topotecan-DNA complexes. Panel A: UV-vis spectrum of the free Tpt (1) and UV-vis (2) and LD (3) spectra of the Tpt - DNA complex. $C_{\mathrm{Tpt}}=1.4 \times 10^{-5} \mathrm{M}, C_{\mathrm{DNA}}=2.25 \times 10^{-4} \mathrm{M}(1 \mathrm{mM}$ cacodylate buffer, $\mathrm{pH}=6.8$; cuvette path length, $1 \mathrm{~cm}$ for UV-vis and $0.1 \mathrm{~cm}$ for $\mathrm{LD}$ experiments). Insert: Projections of the vectors of transition electric dipoles on the plane of the topotecan A-D ring system with the protonated nitrogen of dimethylaminopropylene group and protonated hydroxy group of the ring A. The "+" sign corresponds to deviation of the vector in the direction corresponding to the deviation of the plane of lactone ring $\mathrm{E}$ from the plane of the ring system A-D. Panel B: LD $^{\mathrm{r}}$ spectrum of the Tpt-DNA complex. The spectrum is obtained by division of LD spectrum on the UV-vis spectrum of the Tpt-DNA complex (both spectra are presented in Panel A, curves 3 and 2, respectively).

(data not shown). This correlation of the kinetic of Tpt-DNA binding, followed by FLD, with Tpt hydrolysis, followed by fluorescence spectroscopy, confirms conclusion drawn in ref 11 that only the lactone form of Tpt binds the DNA.

An increase of the DNA concentration from $(2-4) \times 10^{-4}$ $\mathrm{M}$ leads to the LD signal saturation (Figure 1B). At the DNA concentrations corresponding to the saturation of the signal, all Tpt molecules are bound to the DNA. Further increase of the
DNA concentration $\left(>4 \times 10^{-4} \mathrm{M}\right)$ leads to a small decrease of the LD signal.

UV-Vis, Linear Dichroism, and Induced Circular Dichroism Spectra of Topotecan-DNA Complexes. UV-vis and LD spectra of Tpt-DNA complexes were recorded under conditions of complete binding of Tpt molecules with the DNA $\left(C_{\mathrm{DNA}}=2.3 \times 10^{-4} \mathrm{M}\right)$. Figure $2 \mathrm{~A}$ shows the $\mathrm{UV}-$ vis spectrum of the free Tpt (curve 1) and UV-vis (curve 2) and LD (curve 


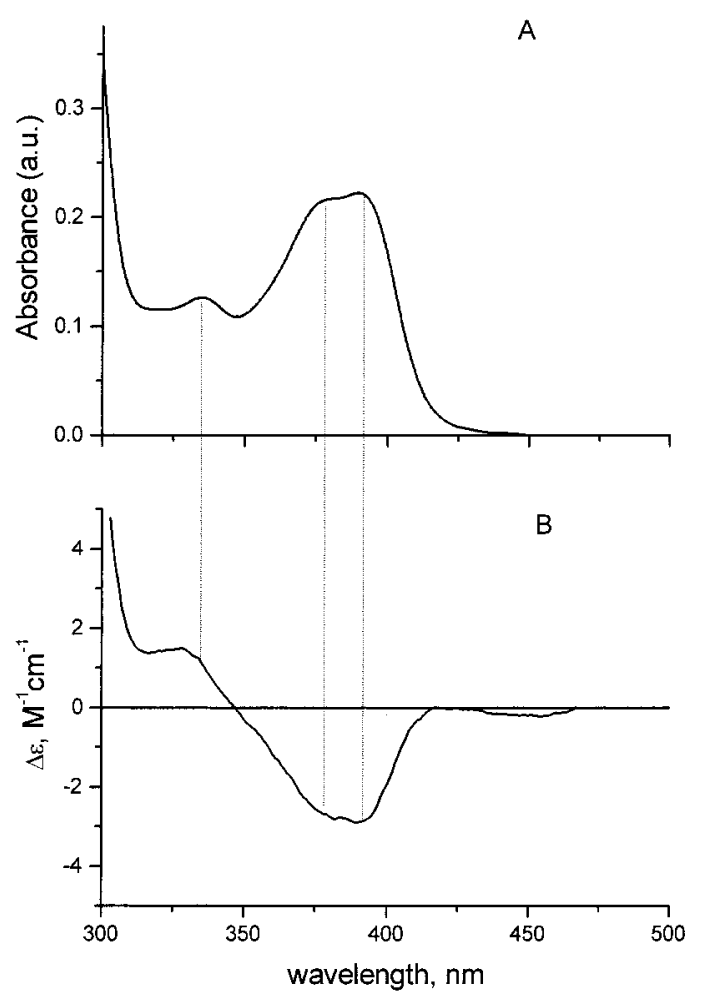

Figure 3. UV-vis (A) and induced CD (B) spectra of DNA-bound topotecan. $C_{\mathrm{Tpt}}=1.4 \times 10^{-5} \mathrm{M}, C_{\mathrm{DNA}}=2.25 \times 10^{-4} \mathrm{M}$, cuvette path lengths 1 and $2 \mathrm{~cm}$, respectively, $1 \mathrm{mM}$ cacodylate buffer, $\mathrm{pH}=6.8$.

3) spectra of Tpt bound with the DNA. We detected the same DNA-induced modifications of the UV-vis spectrum of Tpt as those described in ref 10 .

Figure $2 \mathrm{~B}$ shows the $\mathrm{LD}^{\mathrm{r}}$ spectrum of the Tpt-DNA complex. This spectrum is obtained by division of LD spectrum on the UV-vis spectrum of the Tpt-DNA complex (both spectra are presented in Figure 2A). LD $^{r}$ spectrum of the DNAbound Tpt has a negative sign, and its shape corresponds exactly to the Tpt UV-vis spectrum. (All three) The major (non) antiparallel Tpt long-wavelength electronic transitions (at 390, 375 , and $335 \mathrm{~nm}$ ) are clearly identified in the LD spectrum (Figure 2B).

The $\mathrm{LD}^{\mathrm{r}}$ spectrum of Tpt-DNA complex is easy to interpret. The angles between all Tpt electronic transitions and DNA axis are the same and, according to eq 2 , are close to $55^{\circ}$.

Figure 2 (insert) shows results of quantum chemical calculations of Tpt chromophore in a vacuum. All absorption bands of Tpt in solution are long-shifted compared with the results of calculations, and the band at $380 \mathrm{~nm}$ is splitted. Calculations show only two Tpt electronic transitions (at 352 and $301 \mathrm{~nm}$ ) located in the region $300-450 \mathrm{~nm}$ with the nearly antiparallel orientation of the vectors of their dipole moments. The corresponding bands in the Tpt UV-vis spectrum are found to be at 380 and $327 \mathrm{~nm}$.

Figure 3 shows the ICD spectrum of the DNA-bound Tpt. The ICD signal of Tpt-DNA complex is negative in the region 350-410 $\mathrm{nm}$ and contains all Tpt long-wavelengths electronic transitions presenting in the corresponding UV-vis spectrum.

Sequence Specificity of Topotecan-DNA binding. The sequence specificity of the Tpt-DNA interaction was analyzed by comparative FLD studies of the Tpt binding with the poly(dG)poly $(\mathrm{dC})$, poly $(\mathrm{dG}-\mathrm{dC})$ poly $(\mathrm{dG}-\mathrm{dC})$, poly $(\mathrm{dA}-\mathrm{dT})$ poly$(\mathrm{dA}-\mathrm{dT})$, and poly $(\mathrm{dA})$ poly $(\mathrm{dT})$ polymers and with the CT DNA and bacteriophage T4 DNA.

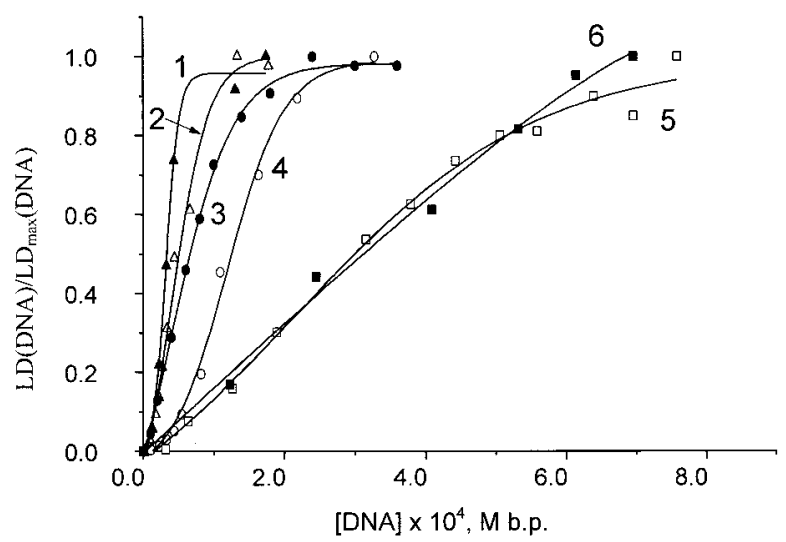

Figure 4. DNA-bound fraction of topotecan $(\theta=\mathrm{LD}(\mathrm{DNA}) /$ $\left.\mathrm{LD}_{\max }(\mathrm{DNA})\right)$ as a function of DNA concentration. Topotecan was bound with the poly $(\mathrm{dG}-\mathrm{dC}) \operatorname{poly}(\mathrm{dG}-\mathrm{dC})($ curve 1$)$, poly $(\mathrm{dG}) \operatorname{poly}(\mathrm{dC})$ (curve 2), bacteriophage T4 DNA (curve 3), calf thymus DNA (curve 4), poly(dA)poly(dT) (curve 5), and poly(dA-dT)poly(dA-dT) (curve $6)$. The measurements of FLD were done in the maxima of the LD spectra of DNA-bound topotecan $(390 \mathrm{~nm}) . C_{\mathrm{Tpt}}=1.4 \times 10^{-5} \mathrm{M}, 1$ $\mathrm{mM}$ cacodylate buffer, $\mathrm{pH}=6.8$, cuvette path length $0.1 \mathrm{~cm}$.

Because the DNAs used have the different length, their degrees of orientation (parameter $S$, see Experimental Section) should be different, and the absolute LD signals, according to expression 1, should be also different, indeed. So to compare the affinities of Tpt to the different DNAs, the dependencies of the fraction of the DNA-bound ligand on the total DNA concentration have been compared. The fraction of DNA-bound ligand $(\theta)$ may be calculated as a ratio of the LD signal for the given DNA concentration ( $\mathrm{LD}(\mathrm{DNA})$ ) to the maximal value of $\mathrm{LD}$ signal ( $\left.\mathrm{LD}_{\max }(\mathrm{DNA})\right): \theta=\mathrm{LD}(\mathrm{DNA}) / \mathrm{LD}_{\max }(\mathrm{DNA})$, were the LD signal is measured in the maximum of absorption of the DNA-bound Tpt (390 nm).

Figure 4 shows the DNA-bound Tpt fractions as a function of the DNAs concentrations. $\theta_{1 / 2}^{1 / 2}$ (the value of the $\theta$, corresponding to the binding of the half of the Tpt molecules) was found to be equal to $0.034,0.050,0.124,0.307$, and $0.307 \mathrm{mM}$ for poly $(\mathrm{dG}-\mathrm{dC}) \operatorname{poly}(\mathrm{dG}-\mathrm{dC})$, poly $(\mathrm{dG}) \operatorname{poly}(\mathrm{dC})$, CT DNA, poly $(\mathrm{dA}) \operatorname{poly}(\mathrm{dT})$, and poly $(\mathrm{dA}-\mathrm{dT}) \operatorname{poly}(\mathrm{dA}-\mathrm{dT})$, respectively. It should be noted that the profiles of the all FLD spectra of Tpt complexes with DNA polymers are very similar.

Figure 4 shows that $\mathrm{Tpt}$ has higher affinity for poly $(\mathrm{dG}-$ $\mathrm{dC}) \operatorname{poly}(\mathrm{dG}-\mathrm{dC})$ and poly $(\mathrm{dG})$ poly $(\mathrm{dC})$ (plateaus of signal saturation were reached at $0.1 \mathrm{mM}$ DNA concentrations) than for poly $(\mathrm{dA}-\mathrm{dT}) \operatorname{poly}(\mathrm{dA}-\mathrm{dT})$ and poly $(\mathrm{dA})$ poly $(\mathrm{dT})$ (no plateau reached up to $0.7 \mathrm{mM}$ DNA concentration), whereas its affinities for the calf thymus DNA and bacteriophage T4 DNA are intermediate between those for $\mathrm{dGdC}$-rich and dAdT-rich polymers. The binding of Tpt to bacteriophage T4 DNA (in which the major groove is occluded by $\alpha$-glycosylated cytosine residues) ${ }^{27,28}$ shows that the shape of FLD curve is very similar to this for the calf thymus DNA-bound Tpt fraction (compare curves 3 and 4 in Figure 4). Moreover, the Tpt demonstrates even higher affinity to the bacteriophage T4 DNA than to the CT DNA.

Competitive Binding of Topotecan and Distamycin A with the Calf Thymus DNA. Figure 5A shows the LD spectra of the Tpt-DNA complexes in the presence of different concentrations of distamycin A. Concentrations of DNA and of Tpt were kept constant and equal to $2.25 \times 10^{-4} \mathrm{M}$ bp, and $1.4 \times 10^{-5}$ $\mathrm{M}$, respectively - the conditions corresponding to the total $\mathrm{Tpt}$ binding to DNA (Figure 1). An increase of the distamycin A concentration induces an increase of the positive LD signal of the DNA-bound distamycin A at $320 \mathrm{~nm}$, as well as a decrease 

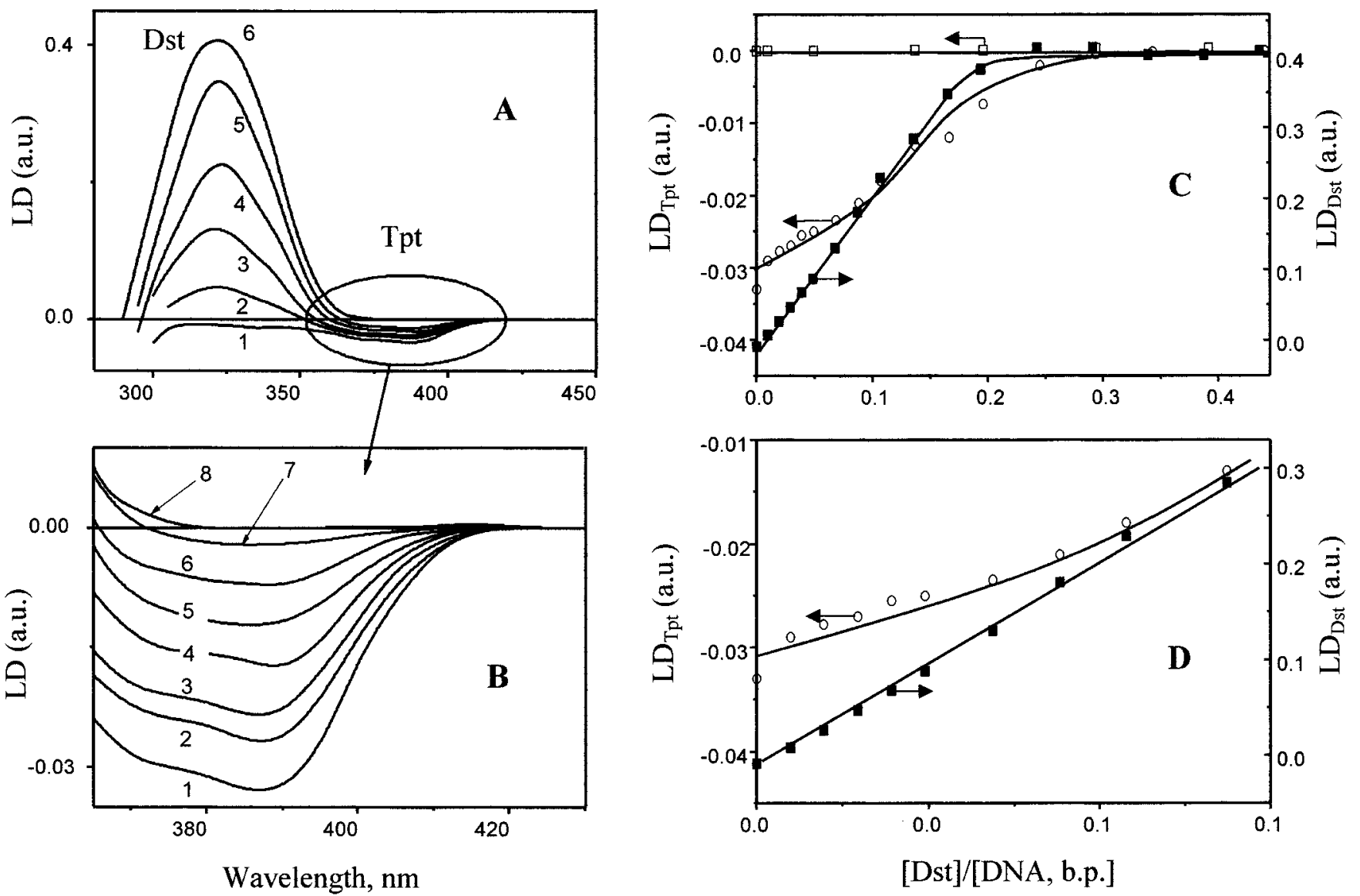

Figure 5. Competitive DNA binding by topotecan and distamycin A. Panel A: LD spectra of the Tpt-CT DNA complexes in the presence of different concentrations of distamycin A (curves 1-6). The regions of the Tpt and distamycin A signals are indicated on the spectra. The [Dst]/ [DNA bp] molar ratios are 0 (1), 0.03 (2), 0.07 (3), 0.11 (4), 0.17 (5), and 0.45 (6). Concentrations of Tpt and DNA were kept constant and equal to $1.4 \times 10^{-5} \mathrm{M}$ and $2.25 \times 10^{-4} \mathrm{M}$, respectively. Panel B: The magnified region of the DNA-bound topotecan LD signal in the presence of different concentrations of distamycin A. The [Dst]/[DNA bp] molar ratios are 0 (1), 0.03 (2), 0.07 (3), 0.11 (4), 0.17 (5), 0.20 (6), 0.25 (7), and 0.45 (8). The other conditions are the same as those in panel A. Panel C: LD signals at $390 \mathrm{~nm}$ (maxima of the LD spectra of DNA-bound Tpt) and LD signals at $320 \mathrm{~nm}$ (maxima of the LD spectra of DNA-bound distamycin A) as a function of the [Dst]/[DNA bp] molar ratios. ( $\square-\square$ ): control, DNA without Tpt. $(\mathrm{O}-\mathrm{O})$ : LD signal of the Tpt-DNA complex. $(\diamond-\diamond)$ : LD signal of the distamycin A-DNA complex. The samples were prepared in the same manner as that in panel A. Panel D: The same as that in panel C for the low [Dst]/[DNA bp] molar ratios. All measurements were proceeded in $1 \mathrm{mM}$ cacodylate buffer, $\mathrm{pH}=6.8$, cuvette path length $0.1 \mathrm{~cm}$.

of the negative signal of the DNA-bound Tpt (Figures $5 \mathrm{~A}$ and B). An increase of the distamycin A concentration up to the 0.35 [Dst]/[DNA bp] molar ratio leads to a decrease of the $\mathrm{LD}$ signal of Tpt down to zero (curve 8, Figure 5B). Further increase of the distamycin A concentration does not induce any modification of the LD spectrum of DNA-bound Tpt.

Figure 5C,D shows the maximal values of the LD signals of DNA-bound Tpt, and of the DNA-bound distamycin A as a function of [Dst]/[DNA bp] molar ratios. The initial slope of the curve corresponding to the LD signal of the DNA-bound distamycin A ([Dst]/[DNA bp] < 0.15) is linear, whereas an initial slope of the curve corresponding to decrease of LD signal of the DNA-bound Tpt is not linear at the low [Dst]/[DNA bp] ratios (Figure 5D), but it becomes linear at higher [Dst]/[DNA bp] ratios. Both curves reach saturation (the maximum signal for the distamycin A-DNA complex and the zero signal for the Tpt-DNA complex) at the [Dst]/[DNA bp] ratios $\sim 0.35$. It should be noted that the contribution of the LD signal of distamycin A in the region of $390 \mathrm{~nm}$ (used for analysis of TptDNA binding) is negligible (Figure $5 \mathrm{~A}$ ).

To check if distamycin A, a well-known AT-specific DNA binder, is able to compete with topotecan for the DNA GC sequences at the low-salt conditions, the detailed analysis of $\mathrm{Tpt}-$ distamycin A competitive binding with poly $(\mathrm{dG}-\mathrm{dC})$ poly-
$(\mathrm{dG}-\mathrm{dC})$ has been proceeded. Figure 6 shows that an increase of the distamycin A concentration induces an increase of the $\mathrm{LD}$ signal of the poly $(\mathrm{dG}-\mathrm{dC})$ poly $(\mathrm{dG}-\mathrm{dC})$-bound distamycin $\mathrm{A}$ at $320 \mathrm{~nm}$ (Panel A), accompanied by the proportional decrease of signal of the poly $(\mathrm{dG}-\mathrm{dC})$ poly $(\mathrm{dG}-\mathrm{dC})$-bound $\mathrm{Tpt}$ (Panel B). Moreover, Figure 6C shows that distamycin A-poly$(\mathrm{dG}-\mathrm{dC})$ poly $(\mathrm{dG}-\mathrm{dC})$ binding induces the $\mathrm{LD}$ spectrum of the same sign and the same profile as that for the binding with the DNA at the saturating concentration of the distamycin A. It means that at our experimental conditions distamycin A forms the same type of complexes with the DNA and poly $(\mathrm{dG}-\mathrm{dC})$ $\operatorname{poly}(\mathrm{dG}-\mathrm{dC})$.

Raman Spectra of Topotecan in Solution and TopotecanDNA and Topotecan-Nucleosides Complexes. The detailed vibrational assignment of the Tpt Raman-active modes based on the normal modes frequencies calculations and comparative spectral analysis of CPT derivatives solutions in $\mathrm{H}_{2} \mathrm{O}, \mathrm{D}_{2} \mathrm{O}$, and organic solvents will be published elsewhere. ${ }^{29}$ The most prominent bands and their assignment in the Raman spectra of lactone form of topotecan are indicated in the top trace of Figure 7. Characteristic Raman spectral features of Tpt are as follows: (i) A doublet of bands at 1650 and $1658 \mathrm{~cm}^{-1}$ results from splitting of $v(\mathrm{C}=\mathrm{O})$ vibration of Tpt lactone ring due to Fermiresonance with the combination tone and/or first overtone of 

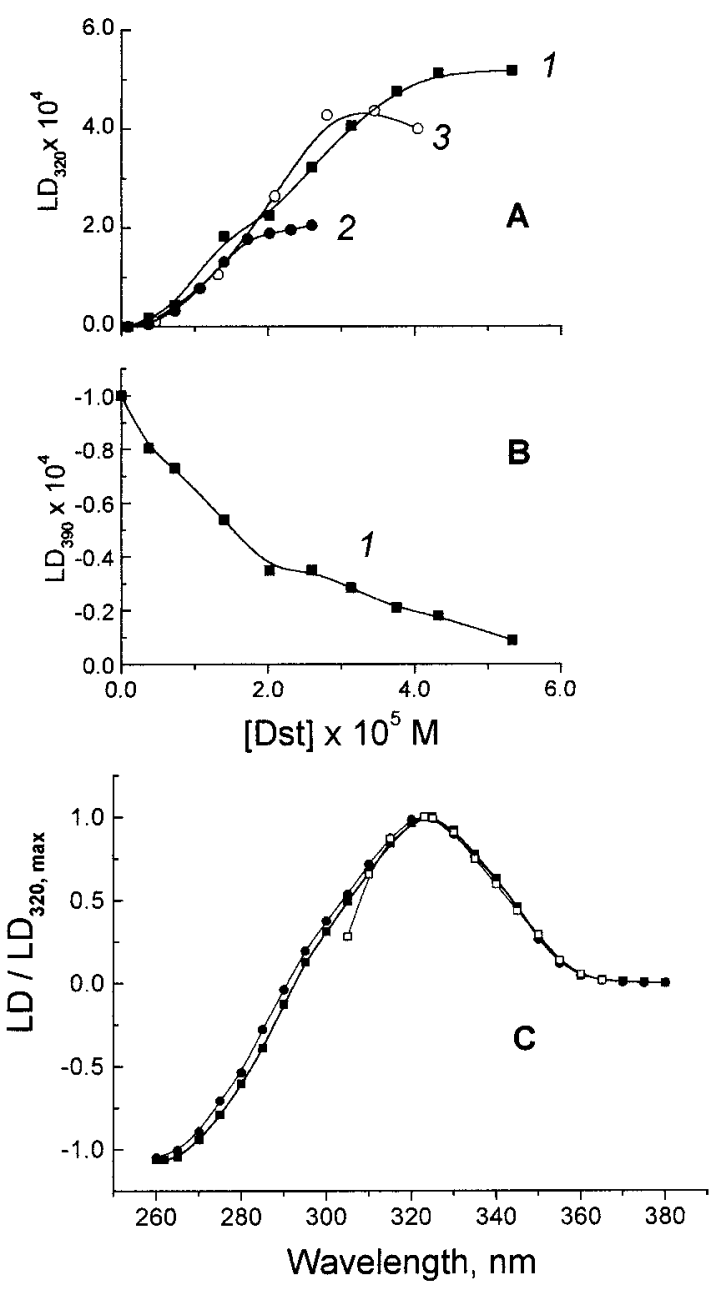

Figure 6. LD spectra of poly $(\mathrm{dG}-\mathrm{dC}) \operatorname{poly}(\mathrm{dG}-\mathrm{dC})$ and $\mathrm{DNA}$ complexes with topotecan in the presence of different concentrations of distamycin A. Panels A and B: LD signals at $320 \mathrm{~nm}$ (maxima of the LD spectra of DNA-bound distamycin A) and at $390 \mathrm{~nm}$ (maxima of the LD spectra of DNA-bound Tpt), recorded from the Tpt-poly$(\mathrm{dG}-\mathrm{dC})$ poly $(\mathrm{dG}-\mathrm{dC})$ complex and from poly $(\mathrm{dG}-\mathrm{dC})$ poly $(\mathrm{dG}-\mathrm{dC})$ in solution as a function of distamycin A concentration. $(\diamond-\diamond)$ : LD signal from complex of $1.05 \times 10^{-5} \mathrm{M}$ Tpt and $8.73 \times 10^{-5} \mathrm{M}$ poly$(\mathrm{dG}-\mathrm{dC})$ poly $(\mathrm{dG}-\mathrm{dC})(1) .(-)$ : LD from $4.36 \times 10^{-5} \mathrm{M}$ poly$(\mathrm{dG}-\mathrm{dC})$ poly $(\mathrm{dG}-\mathrm{dC})$ in solution $(2) .(\mathrm{O}-\mathrm{O})$ : $\mathrm{LD}$ from $8.73 \times 10^{-5}$ M poly $(\mathrm{dG}-\mathrm{dC})$ poly $(\mathrm{dG}-\mathrm{dC})$ in solution (3). Panel C: LD spectra of CT DNA, the Tpt-DNA complex, and the Tpt-poly $(\mathrm{dG}-\mathrm{dC})$ poly$(\mathrm{dG}-\mathrm{dC})$ complex in the presence of saturating concentrations of distamycin A. Spectra are normalized on the $\left(\mathrm{LD}_{320}\right)_{\max }$ signal characteristic for each spectrum. $(\diamond-\diamond)$ Spectrum of complex of 1.05 $\times 10^{-5} \mathrm{M}$ Tpt and $1.15 \times 10^{-4} \mathrm{M}$ DNA in the presence of $4.32 \times$ $10^{-5} \mathrm{M}$ distamycin A. (-): Spectrum of complex of $1.15 \times 10^{-4}$ M DNA and $4.32 \times 10^{-5} \mathrm{M}$ distamycin A. $(\square-\square)$ : Spectrum of complex of $1.05 \times 10^{-5} \mathrm{M}$ Tpt and $8.73 \times 10^{-5} \mathrm{M}$ poly $(\mathrm{dG}-\mathrm{dC})-$ poly $(\mathrm{dG}-\mathrm{dC})$ in the presence of $5.33 \times 10^{-5} \mathrm{M}$ distamycin $\mathrm{A}$. The samples were prepared in the same manner as taht in Figure 5.

the $\mathrm{C}-\mathrm{C}$ stretching vibration of lactone ring. ${ }^{30,31}$ The positions and relative intensities of these bands depend on the ring strain and conjugation within the lactone ring, where reduced ring strain and conjugation both contribute to lowering of the $v(\mathrm{C}=$ O) frequency. ${ }^{31}$ The lowering of the $v(\mathrm{C}=\mathrm{O})$ frequency may be also induced by the carbonyl binding with proton donor group.

(ii) Coupled $\mathrm{C}-\mathrm{O}$ stretching and $\mathrm{O}-\mathrm{H}$ in-plane bending vibrations contribute in the band at $1309 \mathrm{~cm}^{-1}$ and the band $1563 \mathrm{~cm}^{-1}$ is assigned to the ring stretching mode coupled with $v(\mathrm{C}-\mathrm{O})$ vibration.

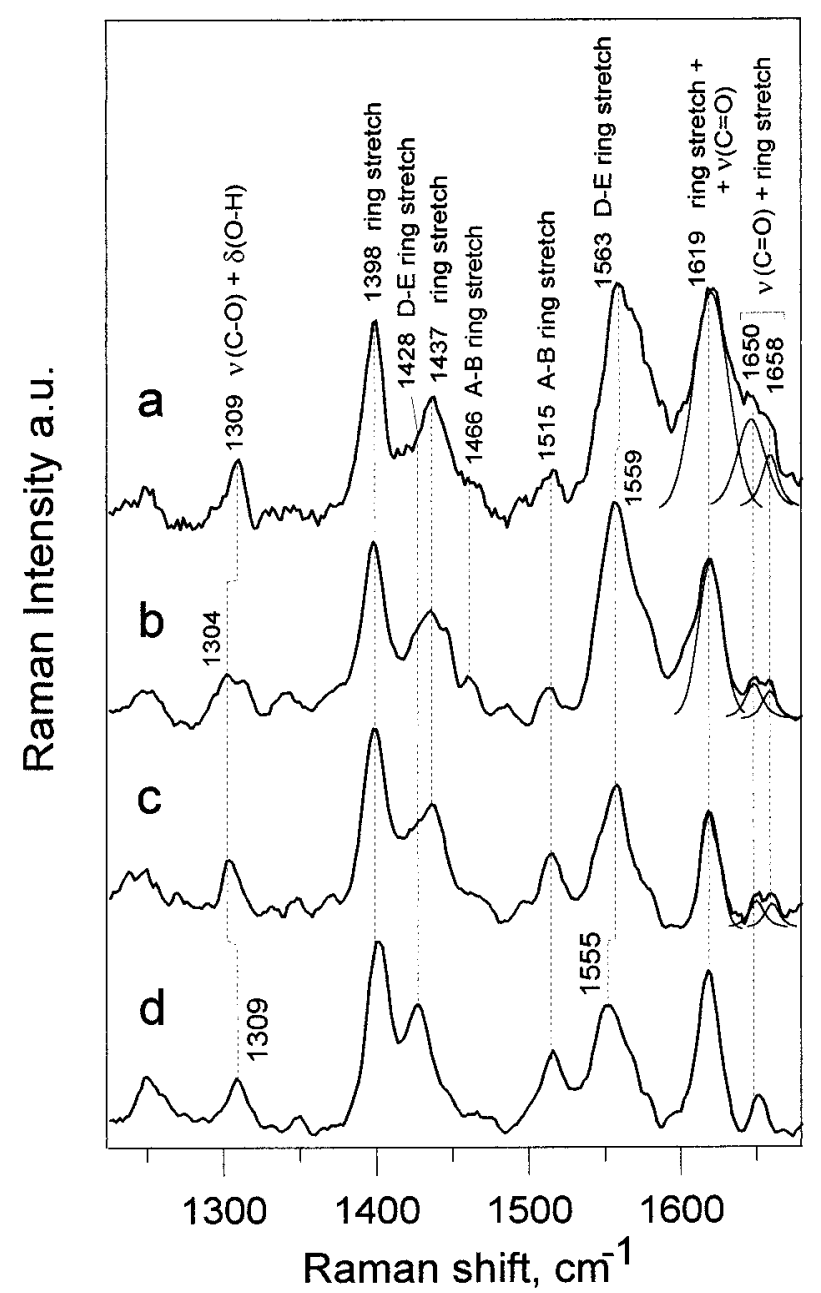

Figure 7. Raman spectra of topotecan free (a) and topotecan bounded with calf thymus DNA (b), with dG (c), and with dI (d). The spectra were obtained by subtracting of Raman spectra of free nucleosides or DNA from the spectra of corresponding complexes. Excitation wavelength was $647.1 \mathrm{~nm}$, and the laser power on the sample was $200 \mathrm{~mW}$. The spectra were recorded in $1 \mathrm{mM}$ cacodylate buffer, $\mathrm{pH}=6.8$, [Tpt] $=10^{-4} \mathrm{M} ; \mathrm{Tpt} /(\mathrm{DNA}$ base) and Tpt/nucleoside molar ratios were $1 / 25$ and $1 / 23$, respectively.

(iii) The band at $1619 \mathrm{~cm}^{-1}$ corresponds to the $\mathrm{D}-\mathrm{E}$ ring stretching vibrations.

Comparison of Raman spectra of Tpt in solution and in complex with DNA (Figure 7) shows that the DNA binding induces the following differences in the Tpt spectrum: (i) the band at $1309 \mathrm{~cm}^{-1}$ is downshifted to $1304 \mathrm{~cm}^{-1}$ under the complexation, (ii) the ring stretch band at $1563 \mathrm{~cm}^{-1}$ is downshifted to $1559 \mathrm{~cm}^{-1}$, (iii) the ratio of intensities within the Fermi-resonance doublet of bands at 1650 and $1658 \mathrm{~cm}^{-1}$ $\left(I_{1658} / I_{1650}\right)$ is increased from 0.6 to 0.9 , and (iv) the ratio of intensities of stretching vibrations at 1619 and $1563 \mathrm{~cm}^{-1}\left(I_{1619} /\right.$ $\left.I_{1563}\right)$ is decreased from 1.0 to 0.7 .

To understand the Raman spectral signatures associated with the Tpt-DNA binding, the Raman spectra of Tpt in the complexes with the $\mathrm{dA}, \mathrm{dC}, \mathrm{dT}, \mathrm{dI}$, and $\mathrm{dG}$ nucleosides in solutions have been recorded. Figure 7 shows that the spectral characteristics of $\mathrm{Tpt}-\mathrm{dG}$ complex are very similar to those for the Tpt-DNA complex: the downshift of the bands at 1309 and $1563 \mathrm{~cm}^{-1}$ and the same modifications of intensity ratios $I_{1658} / I_{1650}$ and $I_{1619} / I_{1563}$. Raman spectra of Tpt complexes with the nucleosides $\mathrm{dI}, \mathrm{dA}, \mathrm{dC}$, and $\mathrm{dT}$ are found to be very similar to each other (only the spectrum of $\mathrm{Tpt}-\mathrm{dI}$ is presented in Figure 7 as an example) but different from the Tpt-DNA and Tpt- 
$\mathrm{dG}$ complexes. The most interesting fact is that the Raman spectrum of the Tpt-dI complex is very different from this for $\mathrm{Tpt}-\mathrm{dG}$ or Tpt-DNA but very similar to the spectra of Tpt complexes with dA, dT, or dC. So the absence of $\mathrm{dG} \mathrm{NH} \mathrm{NH}_{2}$ group (the only one difference between the $\mathrm{dG}$ and $\mathrm{dI}$ chemical structures) induces dramatic change in the mode of $\mathrm{Tpt}-$ nucleoside interaction.

The common features, which distinguish Raman spectra of Tpt complexes with dA, dC, dT, and dI from Tpt-DNA or Tpt$\mathrm{dG}$ complexes, are as follows:

(i) the band at $1309 \mathrm{~cm}^{-1}$ is not shifted in comparison with unbounded Tpt,

(ii) the ratio $I_{1619} / I_{1563}$ does not change or increases to $I_{1619} /$ $I_{1563}=1.3$, whereas it decreases for the Tpt complexes with DNA or $\mathrm{dG}$,

(iii) band $1658 \mathrm{~cm}^{-1}$ completely disappears or has very small intensity, and

(iv) a new spectral band near $1428 \mathrm{~cm}^{-1}$ attributed to D-E rings stretching vibrations is appeared instead of the band 1437 $\mathrm{cm}^{-1}$ observed in Raman spectra of Tpt in solution or of Tpt complexes with DNA or dG.

Raman spectroscopy is an extremely sensitive tool for analysis of the conformational and local structural DNA modifications induced by different effectors. ${ }^{32}$ It should be noted that no changes in the DNA Raman bands were found in the Raman spectra of DNA-Tpt and DNA-distamycin A complexes under the used experimental conditions.

\section{Discussion and Conclusion}

Although the crystal structures of noncovalent and covalent top1 complexes with the oligonucleotides have been recently solved, ${ }^{12,13}$ the role of CPT-DNA interactions in solution and in the so-called "ternary cleavable complex" between the drug, DNA and enzyme remains to be defined. Recent studies have shown that the Tpt interacts directly with double-stranded DNA and this interaction stabilizes its active lactone form. ${ }^{10}$ Although the further NMR studies confirmed that the lactone form of Tpt binds noncovalently the double-stranded and single-stranded DNA structures in the absence of top 1,11 the data on the sequence specificity of the Tpt-DNA binding are contradictory. Yao et al. reported sequence specificity of Tpt lactone binding to alternating purine- pyrimidine sequences that contained dT, ${ }^{11}$ whereas Yang et al. described specific Tpt binding to dGdC rather than to dAdT sequences. ${ }^{10}$ No data on the molecular structure of Tpt-DNA complexes in solution are published to date. We have employed FLD, UV-vis, CD, and Raman spectroscopy to analyze the sequence specificity, geometry, and molecular interactions of Tpt with calf thymus and bacteriophage T4 DNA and with the double-stranded polynucleotides in solution in the absence of DNA topoisomerase I.

FLD spectroscopy is a well-established technique for determination of orientation of transition moment of drug chromophore with respect to the DNA helix long axis. ${ }^{19,22}$ An intercalating mode of ligand-DNA interaction is characterized normally by a negative $\mathrm{LD}^{\mathrm{r}}$ signals in the region of the ligand's long-wavelength absorption bands. ${ }^{19}$ The angles $\alpha$ for typical intercalators are known to be as follows: ethidium bromide, $70^{\circ}$; actinomycine $\mathrm{D}, 61^{\circ}$; proflavine, $82^{\circ}$; 9-aminoacridine, $70^{\circ} .{ }^{21}$ On the other hand, the DNA complexes where the ligands electronic transitions are oriented nonparallel to the plane of the DNA base pares are characterized by the positive LD signals. ${ }^{19}$ The angles $\alpha$ for some of the DNA minor groove binders are known to be as follows: distamycin A, 46 $6^{\circ}, 22,33$ Hechst $33258,45^{\circ} ;{ }^{34}$ DAPI, $43-46^{\circ} .{ }^{35}$ Tpt exhibits the negative
$\mathrm{LD}^{\mathrm{r}}$ signal (Figure 2B), but the value of this signal is much less negative than those for typical intercalators. ${ }^{19}$

Otherwise, the orientation of Tpt chromophore with respect to the plane of the DNA base pairs is quite different from the typical angles of the minor groove binders. According to the examples presented here, orientation of the Tpt chromophore $\left(\alpha_{\mathrm{Tpt}}=55^{\circ}\right)$ is an intermediate between the typical intercalators and the typical DNA minor groove binders. It is interesting to note that this angle coincides with those measured for the minor groove binder bleomycin. ${ }^{36}$

The Tpt molecule includes two main chromophores: the A and $\mathrm{B}$ rings (quinoline part of the molecule) and the $\mathrm{D}$ ring with the nonaromatic hydrolyzable E ring (Figure 1, insert). The quinoline part of the chromophore determines the main electronic properties of the CPT drugs. ${ }^{37}$ The Tpt molecule has a single asymmetrical carbon, located at position 20 . Since the Tpt has a planar and almost completely achiral chromopore, only the molecules complexed to the asymmetric DNA matrix display induced CD. This ICD signal, which is indicative of stacking interactions between the drug and host DNA duplex, can be used to detect and to monitor any CD-active DNA binding mode(s). ${ }^{35}$ ICD signals for all the bands of DNA-bound Tpt in the $350-450 \mathrm{~nm}$ region are negative (Figure $3 \mathrm{~B}$ ). The theory of nondegenerate and degenerate coupled oscillators shows that the sign of ICD signals is determined by the angle between the directions of the ligand chromophore long-axis and of the DNA base pair electronic transition. ${ }^{19}$ If the direction of the polarized electronic transition of the ligand is nearly parallel to the direction of the electronic transition of the DNA base pairs, the ICD signal should be negative. If the long axis is issued from the DNA groove, the positive ICD signal will be induced. ${ }^{19}$ So the ICD of DNA-bound Tpt is typical for the nearly parallel orientation of its long-wavelength electronic transition relative to the plane of the DNA bases, but the value of this signal is much lower than that for intercalators. Finally, the FLD and ICD analysis of Tpt-DNA complexes demonstrated intermediate between the typical intercalators and typical minor groove binder orientation of $\mathrm{Tpt}$ chromophore accompanied by the weak stacking interaction with the DNA base(s).

The FLD spectra presented in Figure 4 demonstrate the DNA sequence preference of Tpt binding. The Tpt affinities are found to be as follows: poly $(\mathrm{dG}-\mathrm{dC})$ poly $(\mathrm{dG}-\mathrm{dC}) \sim \operatorname{poly}(\mathrm{dG})$ poly$(\mathrm{dC})>$ CT DNA $(42 \%$ of GC-pairs $)>\operatorname{poly}(\mathrm{dA}) \operatorname{poly}(\mathrm{dT}) \sim$ poly $(\mathrm{dA}-\mathrm{dT})$ poly $(\mathrm{dA}-\mathrm{dT})$. The data show that the Tpt-DNA affinity does not depend on the relative position of the $\mathrm{dG}$ and $\mathrm{dC}$ or $\mathrm{dA}$ and $\mathrm{dT}$, but obviously decreases upon the decrease of the $\mathrm{dG}-\mathrm{dC}$ content of the DNA.

The FLD and ICD experiments discussed above did not help to identify the DNA groove preference of Tpt binding. Analysis of Tpt binding with the bacteriophage T4 DNA and experiments for competitive DNA binding by Tpt and distamycin A have been proceeded in order to answer this question. The major groove of bacteriophage T4 DNA is occluded by $\alpha$-glycosylated cytosine residues. ${ }^{27,28}$ Figure 4 shows that the Tpt have even higher affinity to bacteriophage T4 DNA than to the CT DNA, and the profiles of corresponding FLD spectra for these two Tpt complexes are practically identical. So the blocking of the Tpt access to the DNA major groove with the glycosyl chains does not influence the structure of Tpt-DNA complexes, nor the Tpt affinity to the DNA. The slightly higher affinity of Tpt to bacteriophage T4 DNA may be explained by higher GC content of bacteriophage DNA compared with that of the CT DNA. Hypothesis of the minor groove DNA preference of Tpt 
binding was further confirmed by the FLD analysis of competitive DNA binding by Tpt and distamycin A.

Distamycin A is a typical DNA minor groove binder, which occupies five base pairs ${ }^{38}$ and exhibits an extremely high affinity of DNA AT-rich regions binding. ${ }^{39}$ It should be noted that the AT specificity of distamycin A is the most prominent at the high ionic strength, whereas it binds pretty well the GCrich and mixed DNA sequences at the low $(<10 \mathrm{mM} \mathrm{NaCl})$ ionic strength of solution. ${ }^{40}$ Distamycin A absorption and its positive LD signal in the DNA-bound state with the maxima at $320 \mathrm{~nm}$ are quite distant from this for the DNA-bound Tpt (390 $\mathrm{nm}$ ). This makes distamycin A useful for the studies of its competitive with the Tpt binding to DNA.

The FLD analysis shows that distamycin A competes with the Tpt in the process of DNA binding (Figure 5). Addition of distamycin A does not change the profile of the LD spectrum of the DNA-bound Tpt but affects only the absolute value of its signal. This fact shows that the distamycin A-DNA binding does not modify the structure of the Tpt-DNA complexes. Moreover, Figure 6 shows that at our experimental conditions, distamycin A replaces topotecan from the GC sequences and the sign and profile of LD signal for distamycin-poly $(\mathrm{dG}-\mathrm{dC})$ poly $(\mathrm{dG}-\mathrm{dC})$ complex are the same as those for the distamycin-DNA complex. The last fact means that the structure of distamycin - poly $(\mathrm{dG}-\mathrm{dC})$ poly $(\mathrm{dG}-\mathrm{dC})$ complex is very similar to that for distamycin-DNA complex. ${ }^{36}$

One may explain distamycin A-induced decrease of DNAbound Tpt as a result of the long-range effect of DNA structural perturbations induced by distamycin A. It should be noted, however, that no any effects of DNA structural perturbation have been detected by the CD and Raman spectroscopy at the all drug/DNA bp ratios used in described experiments. The data support the mechanism of direct competitive replacement of DNA-bound Tpt by the distamycin A molecule rather than dissociation of the Tpt-DNA complexes due to the long-range effect of the DNA structural perturbations induced by the distamycin A.

The difference in dependences of distamycin A-DNA and Tpt-DNA LD signals at the low [Dst]/[DNA bp] ratios (Figure 5D) may be explained by the AT specificity of distamycin A-DNA binding, whereas the Tpt shows the GC specificity. An increase of distamycin A concentration at the low ionic strength enable to the drug to bind the GC-rich DNA regions and to replace the Tpt molecules bound to these regions. An increase of the distamycin A concentration up to [Dst]/[DNA $\mathrm{bp}]=0.2$ leads to the saturation of the LD signal of distamycin A (Figure 5C). This [Dst]/[DNA bp] molar ratio corresponds to the maximal distamycin A-DNA binding, when the molecule occupies in the minor groove the region corresponding to five DNA base pairs. ${ }^{38}$ The DNA minor groove becomes completely saturated by the distamycin A molecules, and an additional increase of the distamycin A concentration does not increase its DNA binding and does not modify its spectrum, indeed. Figure 5C shows that at these conditions of complete saturation of DNA minor groove with the distamycin A, the signal of the Tpt-DNA complex becomes negligible.

FLD spectroscopy demonstrated that the Tpt interacts with all double-stranded polynucleotides with the GC specificity (Figure 4). Raman spectroscopy additionally provides us with the detailed molecular signatures of Tpt-DNA interactions. Comparison of the Raman spectra of Tpt complexes with DNA, $\mathrm{dG}, \mathrm{dI}, \mathrm{dA}, \mathrm{dT}$, and dC confirms that the Tpt may interact with all nucleosides, but it clearly demonstrates that the modes of these interactions are very different. These quite low Tpt-AT affinity combined with complicity of multiple modes of its DNA binding may explain reported contradictions in conclusions about the Tpt base preference drawn previously from the UV-vis ${ }^{10}$ and $\mathrm{NMR}^{11}$ experiments.

Raman spectroscopy (Figure 7) shows that the Tpt-DNA and $\mathrm{Tpt}-\mathrm{dG}$ interactions induce the downshift of the $1309 \mathrm{~cm}^{-1}$ band and an appearance of $1658 \mathrm{~cm}^{-1}$ band whereas Tpt interactions with the other nucleosides (including dI) do not. Variations of these two bands may reflect formation of H-bonds involving 20-OH group $\left(1309 \mathrm{~cm}^{-1}\right)$ and carbonyl group (1658 $\mathrm{cm}^{-1}$ ) of E-ring of Tpt. It's interesting to note that the distance between hydrogen atom of 20-OH group and oxygen atom of carbonyl group of lactone ring of Tpt $(2.5 \AA)$ is equal to the distance between hydrogen atom of amino-group and nitrogen of ring of dG. It's reasonable to suggest that the $\mathrm{Tpt}-\mathrm{dG}$ complex may be stabilized by two H-bonds: the first, between carbonyl group of E-ring of Tpt and amino-group of $\mathrm{dG}$, and the second, between the $20-\mathrm{OH}$ group of Tpt and nitrogen of $\mathrm{dG}$, whereas some very recently synthesized CPT derivatives bind the top1-DNA binary complex despite the absence of a substituent at C-20 capable of contributing a donor H-bond. ${ }^{14}$ Finally, the Raman spectroscopy demonstrates the dominant role of $\mathrm{dG}$ in Tpt-DNA specific binding, which may explain the $\mathrm{dG}$-preference of this interaction and provide us with the direct evidence of participation of $\mathrm{dG}$ in Tpt-DNA binding.

Also the question of whether topotecan interacts with DNA in the absence of DNA topoisomerase I is now generally agreed; ${ }^{10,11}$ the data on molecular structure of Tpt-DNA complex(es) in solution in the absence of the enzyme seem to be very important. Our paper provides the first evidence of the direct $\mathrm{D}-\mathrm{E}$ topotecan rings interaction with the DNA in solution-the complex which stabilizes the Tpt lactone form. ${ }^{10,11}$ The CPTs lactone ring stabilization or destabilization in solution (in the absence of the enzyme) is important due to the fact that the lactone form of CPTs is active whereas the carboxylate is not. Effects of humane serum albumin, lipids and other effectors on the stability of $\mathrm{Tpt}^{24,41-43}$ and analysis of the Tpt structure in molecular complexes with HSA in solution in the absence of top $1^{44,45}$ are the subject of extensive studies.

The data in aggregate provide new insight on the molecular basis of Tpt-DNA recognition in solution, which should be taken into account when considering molecular structure of ternary cleavable complexes of CPTs, DNA, and top1. CPTs preferentially enhance DNA breakage by topoisomerase I at sites with $\mathrm{dG}$ at the +1 position on the scissile strand, immediately downstream of the cleavage site. ${ }^{46} \mathrm{dG}$ specificity of Tpt-DNA binding found in this work may play a role in the base preference of topoisomerase poisons in stimulating enzyme-mediated DNA cleavage if the DNA-drug interactions are not completely distorted upon the enzyme binding. The preliminary data on ternary topoismerase I-DNA-topotecan complexes in solution were reported recently, ${ }^{47}$ and the detailed $\mathrm{CD}$ and Raman spectroscopy analysis of these complexes is in progress in our laboratories now.

Acknowledgment. We are grateful to V.V. Petukhov for the skilful technical assistance. This work was supported by grants from the Association Régionale pour la Recherche et Enseignement Superieur (ARERS) and the Association pour la Recherche sur le Cancer (ARC) to I.N. and, in part, by the NATO Grants CLG.977495 and RFBR 00-04-48105 and 9904-48160 (to V.A.), 98-04-49220 01-04-48657 (to A.Z.), 0103-32669 (to S.G.), and 99-04-48156 (to I.K.). A.S. acknowledges Région Champagne-Ardenne for a postdoctoral fellowship 
award, and V.O. acknowledges FEBS for granting a short-term fellowship award.

\section{References and Notes}

(1) Pommier, Y.; Pourquier, P.; Fan, Y.; Strumberg, D. Biochim. Biophys. Acta 1998, 1400, 83, and references herein.

(2) Li, L. H.; Fraser, T. J.; Olin, E. J.; Bhuyan, B. K. Cancer Res. 1972, 32, 2643

(3) Fukada, M. Biochem. Pharmacol. 1985, 34, 1225.

(4) Hsiang, Y.-H.; Hertzberg, R.; Hecht, S.; Liu, L. F. J. Biol. Chem. $1985,260,14873$

(5) Kuwahara, J.; Suzuki, T.; Funakoshi, K.; Sugiura, Y. Biochemistry 1986, 25,1216 .

(6) Hertzberg, R. P.; Caranfa, M. J.; Hecht, S. M. Biochemistry 1989, $28,4629$.

(7) Hertzberg, R. P.; Busby, R. W.; Caranfa, M. J.; Holden, K. G.; Johnson, R. K.; Hecht, S. M.; Kingsbury, W. D. J. Biol. Chem. 1990, 265 , 19287.

(8) Leteurtre, F.; Fesen, M.; Kohlhagen, G.; Kohn, K. W.; Pommier, Y. Biochemistry 1993, 32, 8955.

(9) Fan, Y.; Weinstein, J. N.; Kohn, K. W.; Shi, L. M.; Pommier, Y. J. Med. Chem. 1998, 41, 2216.

(10) Yang, D.; Strode, J. T.; Spielmann, H. P.; Wang, A. H.-G.; Burke, T. G. J. Am. Chem. Soc. 1998, 120, 2979.

(11) Yao, S.; Murali, D.; Seetharamulu, P.; Haridas, K.; Petluru, P. N. V.; Reddy, D. G.; Hausheer, F. H. Cancer Res. 1998, 58, 3782.

(12) Redinbo, M. R.; Stewart, L.; Kuhn, P.; Champoux, J. J.; Hol, W. G. Science 1998, 279, 1504.

(13) Stewart, L.; Redinbo, M. R.; Qiu, X.; Hol, W. G. L.; Champoux, J. J. Science 1998, 279, 1534

(14) Wang, X.; Zhou, X.; Hecht, S. M. Biochemistry 1999, 38, 4374

(15) Fleury, F.; Ianoul, A.; Kryukov, E.; Sukhanova, A.; Kudelina, I.; Wynne-Jones, A.; Bronstein, I.; Maizieres, M.; Berjot, M.; Dodson, G.; Wilkinson, A.; Holden, J.; Feofanov, A.; Alix, A.; Jardillier, J.-C.; Nabiev, I. Biochemistry 1998, 37, 14630.

(16) Taboury, J. A.; Taillandier, E. Nucleic Acid Res. 1985, 13, 4469.

(17) Zimmer, C.Prog. Nucleic Acids Res. Mol. Biol. 1975, 15, 285.

(18) Makarov, V. L.; Streltsov, S. A.; Vengerov, Yu. Yu.; Khorlin, A. A.; Gursky, G. V. Mol. Biol. (Moscow) 1983, 17, 1089. 51. 51.

(20) Hofrichter, J.; Eaton, W. A. Annu. Rev. Biophys. Bioenerg. 1976, 5,511

(21) Hogan, M.; Dattagupta, N.; Crothers, M. Biochemistry 1979, 18, 280.

(22) Sveshnikov, P. G.; Grokhovsky, S. L.; Zhuze, A. L.; Kondrat'eva, N. O.; Makarov, V. L.; Poletaev, A. I. Mol. Biol. (Moscow) 1978, 12, 557.
(23) Bailly, C.; Riou, J.-F.; Colson, P.; Houssier, C.; Rodrigues-Pereira, E.; Prudhomme, M. Biochemistry 1997, 36, 3917.

(24) Dewar, M. J. S.; Zoebisch, E. G.; Healy, E. F.; Stewart, J. P. J. Am. Chem. Soc. 1985, 107, 3902.

(25) Zerner, M. C.; Loew, G. H.; Kirchner, R. F.; Mueller-Westerhoff, U. T. J. Am. Chem. Soc. 1980, 102, 589.

(26) Burke, T. G.; Mi, Z. J. Med. Chem. 1994, 37, 40.

(27) Wyatt, G. R.; Cohen, S. S. Biochem. J. 1953, 55, 774.

(28) Lehman, I. R.; Pratt, E. A. J. Biol. Chem. 1960, 235, 3254.

(29) Oleinikov, V.; Mochalov, K.; Sukhanova, A.; Ustinova, O.; Jardillier, J. C.; Nabiev, I. Biopolymers, in press.

(30) Nyquist, R.; Fouchea, H.; Hoffman, G.; Hasha, D. Appl. Spectrosc. 1991, $45,860$.

(31) Durig, J. R. Spectrochem. Acta 1963, 19, 1225

(32) Peticolas, W. L.; Kubasek, W. L.; Thomas, G. A.; Tsuboi, M. Nucleic Acids. In Biological Applications of Raman Spectroscopy; Spiro, T. G., Ed.; Wiley: New York, 1987; Vol. I.

(33) Streltsov, S. A.; Martinkina, L. P.; Vengerov, Yu. Yu. FEBS Lett. 1999, 444, 231.

(34) Moon, J. H.; Kim, S. K.; Sehlstedt, U.; Rodger, A.; Norden, B. Biopolymers 1996, 38, 593.

(35) Eriksson, S.; Kim, S. K.; Kubista, M.; Norden, B. Biochemistry 1993, 32, 2987.

(36) Bailly, C.; Henichart, J. P.; Colson, P.; Houssier, C. J. Mol. Recognit., 1992, 5, 155 .

(37) Nabiev, I.; Fleury, F.; Kudelina, I.; Pommier, Y.; Charton, F.; Riou, J.-F.; Alix, A. J. P.; Manfait, M. Biochem. Pharmacol. 1998, 55, 1163.

(38) Zasedatelev, A. S.; Zhuze, A. L.; Zimmer, C.; Grokhovsky, S. L.; Tumanyan, V. G.; Gursky, G. V.; Gottikh, B. P. Dokl. Acad. Nauk SSSR 1976, 231, 1006.

(39) Luck, G.; Triebel, H.; Waring, M.; Zimmer, C. Nucleic Acids Res. 1974, 4, 503 .

(40) Zasedatelev, A.; Gursky, G.; Zimmer, C.; Thrum, H. Mol. Biol. Rep., 1974, 1, 337.

(41) Burke, T. G.; Mishra, A. K.; Wani, M. C.; Wall, M. E. Biochemistry 1993, 32, 5352

(42) Mi, Z.; Burke, T. G. Biochemistry 1994, 33, 10325.

(43) Mi, Z.; Burke, T. G. Biochemistry 1994, 33, 12540

(44) Fleury, F.; Kudelina, I.; Nabiev, I. FEBS Lett. 1997, 406, 151.

(45) Fleury, F.; Ianoul, A.; Berjot, M.; Feofanov, A.; Alix, A. J. P.; Nabiev, I. FEBS Lett., 1997, 411, 215.

(46) Tanizawa, A.; Kohn, K. W.; Pommier, Y. Nucleic Acids Res. 1993, $21,5157$.

(47) Nabiev, I; Mochalov, K.; Ustinova, O.; Sukhanova, A.; Jardillier, J. C.; Oleinikov, V. Anticancer Res. 2001, 21, 1551. 